\title{
A Bolivarian People: Identity politics in Hugo Chávez's Venezuela
}

\author{
R. Guy Emerson
}

\section{Abstract}

The 1998 electoral success of Hugo Chávez brought about a dramatic shift in Venezuelan identity. While rhetorically inclusive at first glance, references to the 'Venezuelan people' would not speak to all Venezuelans. Rather, the 'people' would come to denote a previously marginalised segment of society now at the centre of Venezuelan political life. More than a simple reorientation in political focus, this shift in the politics of Venezuelan identity sends out a set of messages that acts as a symbolic boundary to frame, limit and domesticate an official 'Bolivarian' identity. It is the construction of this new official identity assembled, in part, from the ruins of the previous order that concerns this article.

\section{A Bolivarian People: Identity politics in Hugo Chávez's Venezuela}

Hugo Chávez Frías arrived at the Miraflores Presidential Palace as the fiftysecond President of the Republic of Venezuela, promising to dramatically refashion political life. Coming to the presidency during a period of institutional decay and popular exhaustion with traditional political parties, Chávez and his Bolivarian Revolution stood upon the ruins of the Punto Fijo system pledging to consign political corruption and economic hardship to the past. Foremost in the former Lieutenant Colonel's message was the promise to return dignity to both the nation and its people. On the back of this narrative of national renewal began a period of dramatic transformation. The former constitution was consigned to the scrap heap, taking with it the country's bicameral legislative system, while both the national flag and its emblem were modified to affect symbolic change. Not even the name of the country was left untouched, with the South American state becoming the Bolivarian Republic of Venezuela. Beyond these structural and symbolic changes, however, the new Chávez administration would also affect a shift in Venezuelan identity. President Chávez's inaugural address in 1999 pointed to the dimensions of this shift: 'Today, the second of February 
1999, arrives the hour of the Venezuelan people.' ${ }^{1}$ While seemingly inclusive at first glance, the phrase 'Venezuelan people' would not refer to all Venezuelans. Rather, the 'people' denotes a previously marginalised segment of society now at the centre of Venezuelan political life. More than a simple reorientation in political focus, however, Chávez would speak directly to the concerns of the previously marginalised, and later come to superimpose their history over that of the nation. It is specifically this transformation in the official state identity that concerns this article.

Beyond simply trading on the increased inequality that the poor majority faced in the lead-up to the 1998 poll, analysis below takes a broader view of the shift in identity that explores the structural underpinning of Chávez's language as well as the boundaries within which a new official 'Bolivarian' identity operates. It does so by examining the political and historical parameters that greeted Chávez upon his arrival at the presidency and what effect his reading of these factors had on forging a new official identity. How does the Chávez reading of his failed coup d'état attempt in 1992, for example, serve to reinforce both the righteousness of the 'people' and the corruption of the ancien régime? A focus on the materiality of Chávez's discourse asks how, having made an investment in an unjust account of the Venezuelan past, he is then able to draw dividends on these representations so as to solidify calls for change and call forth a 'Bolivarian people'. Accordingly, the analysis below highlights how Chávez works within these structures to promote a particular reading of events - past, present and future - and to sponsor a particular Bolivarian identity. In so doing, it provides an insight into how the symbols, rules, concepts, categories, and meanings elaborated within Bolivarianism shape how the Chávez administration constructs and interprets its people and its world.

\section{Understanding the Shift in the Politics of Identity: From a maligned people to a Bolivarian people}

Explanations of the shift in Venezuelan identity tend to focus on the President himself and his style of leadership. Criticism of Chávez, who is portrayed as a populist, and of his divisive manipulation of social discontent for political gain is generally followed by references to the antagonism he generates through Manichean representations both at home and abroad. ${ }^{2}$ Chávez has developed a politics of inequality, so the argument goes, that mirrors Venezuela's social and economic cleavages between rich and poor, and therefore exacerbates the

1 Cited in Moreno, M. A. 2008, Metaphors in Hugo Chavez's Political Discourse: Conceptualizing nation, revolution, and opposition, The City University of New York, NY, p. 1.

2 Mudde, C. 2002, 'In the name of the peasantry, the proletariat, and the people: populisms in Eastern Europe', in Y. Mény and Y. Surel (eds), Democracies and Populist Challenge, Palgrave, New York, p. 216. 
already polarised identities within the South American nation. ${ }^{3}$ The Bolivarian leader and his United Socialist Party of Venezuela emphasise social discontent so as to outmanoeuvre other parties who are unable or unwilling to adapt to the new socio-political realities. ${ }^{4}$ Moreover, the Bolivarian Revolution is often portrayed as a movement in reaction to past injustices, with the confrontation between rich and poor becoming a 'moral and ethical struggle between el pueblo (the people) and the oligarchy'. ${ }^{5}$ Honest people, positioned at one end of the spectrum, are in open confrontation with the corrupt elites at the other. ${ }^{6}$ While such antagonisms exist in Chávez's Venezuela (and indeed precede his administration), conflating this animosity with a new 'Bolivarian' identity is problematic.

Frequent references to a corrupt oligarchy and a glorious people make it tempting to attribute the shift in identity to a populist style of antagonistic leadership. Contributing to such a view is the continued exclusion of a historically threatening oligarchy. The oligarchy was responsible for the failed 11 April 2002 coup d'état attempt to overthrow his government, Chávez argues, while at the same time they threaten social reforms, as they want to 'turn off, alter the course or neutralise change' within the Bolivarian Revolution. ${ }^{7}$ Bolivarianism - committed to overcoming inequality and restoring justice - is placed in contrast to the corrupt, exploitative oligarchy intent on maintaining their privilege. Undoubtedly, elements of this narrative influence the ideas and identities within Venezuela. Antagonism between el pueblo and la oligarquía is not, however, the basis for the shift in Venezuelan identity. As is demonstrated below, the simple pueblo/oligarquia binary is not capable of authoring identity and difference. Rather, the new identity is multi-layered and depends on a broader narrative rather than its simplest binary part. ${ }^{8}$ Accordingly, this article suggests that a new appreciation of official Venezuelan identity is needed. In so doing, it argues that it is as much an understanding of how the socio-cultural and politico-historical environments are themselves discursively represented as it is the pueblo/oligarquia binary that underpins a new identity and gives Bolivarianism its symbolic boundary.

3 Roberts, K. M. 2003, 'Social correlates of party system demise and populist resurgence in Venezuela', Latin American Politics and Society, vol. 45, no. 3, pp. 35-57.

4 Cannon, B. 2004, 'Venezuela, April 2002: coup or popular rebellion? The myth of a united Venezuela', Bulletin of Latin American Research, vol. 23, no. 3, p. 286.

5 Zúquete, J. P. 2008, 'The missionary politics of Hugo Chávez', Latin American Politics and Society, vol. 50, no. 1, p. 94 .

6 Mény, Y. and Surel, Y. 2002, 'The constitutional ambiguity of populism', in Y. Mény and Y. Surel (eds), Democracies and Populist Challenge, Palgrave, New York.

7 Cited in Harnecker, M. 2002, Hugo Chávez Frías: Un hombre, un pueblo, Editorial de Ciencias Sociales, Havana, pp. 20, 25, 52.

8 Persaud, R. B. 2002, 'Situating race in international relations: the dialectics of civilisational security in American immigration', in G. Chowdhry and S. Nair (eds), Power, Postcolonialism and International Relations: Reading race, gender and class, Routledge, London, p. 66. 


\section{A Breakdown in the Previous Identity}

The construction of a new 'Bolivarian' identity is made possible by a collapse in the previous state narrative of unity and progress. For most of the twentieth century, the promise of modernity served as a powerful narrative to unite Venezuelan society. The Punto Fijo pact signed in 1958 by the three principal political parties enshrined a modernising state at the centre of Venezuelan development. ${ }^{9}$ Designed to lift the South American nation from its economic and social backwardness, the Punto Fijo state would reconcile the complex and often opposing tendencies between a powerful minority and a poor majority. ${ }^{10}$ Rómulo Betancourt, a key architect of Punto Fijo, argued that the modernising state would mediate between the poorer labouring and landless classes, and a 'parasitic elite' that previously had enriched 'themselves at the public expense through political favouritism'. ${ }^{11}$ The placement of the state at the head of the march towards progress served as a coherent and unifying message that claimed to benefit all Venezuelans by relegating exploitation to the past. High levels of revenue derived from oil earnings enabled the Venezuelan state to create an exceptionally sheltered domestic space 'fertile for cultivating hierarchical alliances and weaving illusions of social harmony'. ${ }^{12}$ Increases in social spending maintained the confidence of the majority and enabled the state to channel and coopt popular movements away from revolutionary or radical demands. Literacy rates increased from 51 per cent of the population in 1950 to 88.1 per cent in 1981, while Venezuelan workers benefited from some of the highest wages and the most heavily protected labour market in Latin America. ${ }^{13}$ Similarly, business interests were gradually absorbed into the state apparatus, as the upper classes used their direct access to policy makers and petroleumgenerated rents to pressure for the continued distribution of wealth to certain sectors of the economy that would, in turn, underpin pro-business development policies. ${ }^{14}$

\footnotetext{
9 In addition to the involvement of Acción Democrática (AD), Comité de Organización Politica Electoral Independiente (COPEI) and Unión Republicana Democrática (URD), the Communist Party of Venezuela (PCV) also had popular support as a modernising force. They were, however, explicitly excluded from the Punto Fijo pact - a notable omission given their role against the dictatorship of General Marcos Pérez Jiménez. For more, see Ellner, S. 2008, Rethinking Venezuelan Politics: Class, conflict, and the Chávez phenomenon, Lynne Rienner Publishers, Boulder, Colo.

10 Rey, J. C. 1991, 'La democracia Venezolana y la crisis del sistema populista de conciliación', Revista de Estudios Políticos (Nueva Época), vol. 74 (Octubre-Diciembre), p. 543; Cannon, 'Venezuela, April 2002', p. 289.

11 Cited in Hellinger, D. and Melcher, D. 1998, Venezuela: a welfare state out of gas?, Paper presented at the XXI International Congress of the Latin American Studies Association, 24-26 September, Chicago, p. 3.

12 Coronil, F. and Skurski, J. 1991, 'Dismembering and remembering the nation: the semantics of political violence in Venezuela', Comparative Studies in Society and History, vol. 33, no. 2, p. 312.

13 Roberts, 'Social correlates of party system demise and populist resurgence in Venezuela', p. 47.

14 Crisp, B. F. 1998, 'Lessons from economic reform in the Venezuelan democracy', Latin American Research Review, vol. 33, no. 1, pp. 9, 12.
} 
Within this environment, class cleavages gradually eroded as the Punto Fijo political system allowed both Acción Democrática(AD) and Comité de Organización Politica Electoral Independiente (COPEI) to develop into multi-class, catchall electoral organisations. ${ }^{15}$ An array of policy initiatives and institutions was organised along party lines - from beauty contests and choral societies to trade unions and professional groups - all designed to control societal demands. ${ }^{16}$ The success in uniting its peoples saw the Venezuelan state labelled 'exceptional' for its high levels of stability despite the ongoing political and social turbulence throughout the rest of Latin America. ${ }^{17}$ By the 1980s, however, limits to both Venezuelan stability and the belief in unified progress began to appear.

Amid a deteriorating economic outlook, the 1988 presidential campaign saw former President Carlos Andrés Pérez promise to maintain the wealth and social prosperity associated with the modernising state. ${ }^{18}$ Presiding over the 1974 oil boom in his previous term, Pérez incarnated the myth of oil wealth and progress like no other president in Venezuelan history. ${ }^{19}$ Traversing the country during the 1988 election campaign with the slogans of 'the man with energy' and 'the man who really walks', Pérez reinforced popular beliefs that progress would continue despite the unfavourable economic landscape. Fomenting perceptions of a leader willing to meet popular demands, President Pérez, during his inauguration celebrations, called on debtor nations to lobby against the policies of international banks and the International Monetary Fund (IMF). ${ }^{20}$ Calling for a 50 per cent devaluation of Latin American debt, the Venezuelan President positioned his country as a leader of Latin American interests and their battle against oppressive international financial institutions. ${ }^{21}$ Like Betancourt before him, Pérez placed international exploitation at the forefront of his political narrative. While Betancourt had bemoaned 'the exploitation of our large natural resources' and spoke of defending 'national industry...on behalf of all the people in order to promote national development', Pérez offered a similar message in relation to debt. ${ }^{22}$ With Venezuela one of the World Bank's top20 'highly indebted nations', Pérez labelled the bank's economists 'genocide

\footnotetext{
15 Roberts, 'Social correlates of party system demise and populist resurgence in Venezuela', pp. 58-9.

16 Levine, D. H. 1998, 'Beyond the exhaustion of the model: survival and transformation of democracy in Venezuela', in D. Canache and M. R. Kulisheck (eds), Reinventing Legitimacy: Democracy and political change in Venezuela, Greenwood Press, Westport, Conn., p. 194.

17 Parker, R. 2005, 'Chávez and the search for an alternative to neoliberalism', Latin American Perspectives, vol. 32 , p. 39 .

18 Hellinger, D. 2003, 'Political overview: the breakdown of Puntofijismo and the rise of Chavismo', in S. Ellner and D. Hellinger (eds), Venezuelan Politics in the Chávez Era: Class, polarization, and conflict, Lynne Rienner Publishers, Boulder, Colo., p. 31.

19 Coronil, F. 1997, The Magical State: Nature, money, and modernity in Venezuela, University of Chicago Press, Ill., p. 370.

20 Coronil and Skurski, 'Dismembering and remembering the nation', p. 295.

21 Simon, W. 1989, 'Venezuelan President urges debt relief for Third World nations', The Globe and Mail, 6 February 1989.

22 Coronil, The Magical State, p. 96.
} 
workers in the pay of economic totalitarianism' and described IMF prescriptions as 'la bomba solo-mata-gente' (the bomb that only kills people). ${ }^{23}$ A vote for Pérez thus seemed to reinforce the state's position between what Betancourt had defined as the poorer classes and a 'parasitic elite', in addition to reaffirming the previous redistributive measures of a paternalistic state. Such expectations, however, were short-lived.

In what later became known as 'el gran viraje' (the great turnaround), within a month of his inauguration, President Pérez signed a letter of intent with the IMF and announced his 'paquete económico' of macroeconomic stabilisation that promoted cuts in social spending, trade liberalisation, deregulation and privatisation. ${ }^{24}$ As a consequence of the Pérez reform, the price of subsidised petrol increased immediately by 100 per cent, the bolívar saw an immediate 170 per cent devaluation as a result of being floated, while interest rates were freed and subsequently moved from 13 to 40 per cent. Faced with an immediate increase in food and transport costs, el paquete met with a series of urban protests in 17 cities, collectively known as the Caracazo uprising, which, according to official counts, left 287 people dead, although other sources claim the toll to be as high as $5000 .{ }^{25}$ Pérez's policy about-face coincided with a shift in official rhetoric. The previous talk of independence from foreign domination was replaced with the need to meet IMF prescriptions and conform to austerity measures now described as 'painful but inevitable'.${ }^{26}$ Pérez shattered the myth of progress by disavowing the oil-protected past as an irrational fantasy and instead turned to the free market as the rational means of achieving progress. ${ }^{27}$

More than a simple reorientation in message, however, the Venezuelan President would recast the relationship between the state and the poor majority. Just as previous governments had labelled those opposed to their policy prescriptions as impediments to modernisation, so too did Pérez. In contrast with Betancourt's talk of a 'parasitic elite', however, Pérez was distinguished from his predecessors in that his accusations identified the poor majority as obstacles to progress. In response to the protests, President Pérez sent in the armed forces and suspended

\footnotetext{
23 Cited in Ali, T. 2006, 'A beacon of hope for the rebirth of Bolívar's dream', The Guardian, 9 November 2006.

24 More specifically, Pérez's 'paquete económico' can be split into two parts: the short-term stabilisation measures implemented immediately, and the more medium-term structural reforms meant to permanently reverse the old development strategy. Short-term measures unified all exchange rates and floated the bolívar. Medium-term structural reforms sought to attack every area of government activity. Distortions in the foreign-trade regimes were abolished, all but a few sectors were opened up to private investment, and government enterprises were privatised, while others were significantly restructured to improve delivery of social services. Government borrowing was to be permanently limited, while subsidies for the agricultural sector were removed.

25 For official figures, see Hellinger, 'Political overview'; while for unofficial figures, see Harnecker, M. 2003, 'The Venezuelan military: the making of an anomaly', Monthly Review, vol. 55, no. 4, p. 17.

26 Cited in Simon, W. 1989, '100 said dead in riots; major rights suspended', Reuters News, 28 February 1989.

27 Coronil, The Magical State, p. 370.
} 
civil liberties, claiming 'we must safeguard the right to peace and safeguard the property of our nation', and told the audience in his televised address that 'this will be in your benefit' ${ }^{28}$ Clearly directing his words to the economically well off, Pérez had shifted the state from its position at the centre of Venezuelan society between rich and poor. In a series of attacks, Pérez accused protestors of being 'committed to violence and willing to take advantage of difficult times'.$^{29}$ These attacks intensified throughout the week, with the President describing protestors as 'phantasmagorical remnants of subversives [who] are still not convinced this is a democratic country'. ${ }^{30}$ The depiction of popular sectors as out of control 'subversives' not only reinforced a polarising discourse, but also offered the state a justification for its use of force. ${ }^{31}$ The effect of the bloody crackdown, however, was to further shake assumptions concerning paternalistic state-society relations and reinforce perceptions of a popular class inhibiting the forces of modernity represented by the state and the more prosperous classes. Indeed, perceptions among the upper classes that protestors threatened private property saw the very wealthy leave the country in their private jets, while sectors of the middle class organised armed defence groups to protect their property. ${ }^{32}$ The Caracazo uprising brought to the fore the social cleavages that the state - no longer able to unite all Venezuelans in the march to modernity - had previously absorbed..$^{33}$

With the official reading of the Caracazo differing from the claims of a 'massacre' by the popular classes, both the legitimacy of the state and its narrative of unity in modernisation came into question. As a consequence of state action, the poor majority no longer identified themselves within the official narrative. Far from becoming silent, however, the popular classes appropriated their exclusion and began to create their own counter-narrative. Depicted as an impediment to progress, the newly maligned openly confronted their role within Venezuelan society, crying foul at the silencing and manipulation of their demands. Shouts of 'we are no longer a passive pueblo' became common, while 'el pueblo está bravo' (the people are brave/angry) was scrawled across walls and repeated by protesters. ${ }^{34}$ Appropriating the official signs of nationhood, protesters sang the opening line of the national anthem: 'Gloria al bravo pueblo que el yugo lanzo'

\footnotetext{
28 Cited in Simon, '100 said dead in riots'.

29 Cited in ibid.

30 Cited in Associated Press 1989, 'Soldiers rushed to Caracas to forestall riots', The Globe and Mail, 3 March 1989.

31 Coronil and Skurski, 'Dismembering and remembering the nation', p. 327.

32 Cannon, 'Venezuela, April 2002', p. 290; Coronil and Skurski, 'Dismembering and remembering the nation', p. 320.

33 At the time, the Caracazo constituted the largest and most repressed uprising that modern Latin America had seen. For an excellent analysis of the Venezuelan setting, see Coronil and Skurski ('Dismembering and remembering the nation'), while for a careful comparative analysis of protests in Latin America against debtrelated austerity programs, see Walton, J. 1989, 'Debt, protest and the state in Latin America', in S. Eckstein (ed.), Power and Popular Protest, University of California Press, Berkeley.

34 Coronil and Skurski, 'Dismembering and remembering the nation', p. 318.
} 
(glory to the brave and angry people who threw off their yoke). State repression not only shattered the myth of unified progress, but also opened up new avenues for unexpected meanings and practices to come together in novel ways. ${ }^{35}$

By self-ascribing themselves as the brave people of Gloria al Bravo Pueblo (the national anthem), those officially maligned as 'phantasmagorical subversives' claimed to be representative of the legitimate people of the nation. Although state identities are always in negotiation, this rupture called into question the official identity of Venezuelans as a united people. Indeed, the marginalisation of the popular classes after the Caracazo would not only place in contradistinction rival identity claims over who were the authentic representatives of the nation, but it would also juxtapose rival interpretations of the events of February 1989. Claims of a 'popular uprising' and a 'massacre' interacted with official assertions that neutrally labelled the conflict ' $27-\mathrm{F}^{\prime}$ and 'the events'. ${ }^{36}$ While it would ultimately take 10 years, Hugo Chávez would best acknowledge this rupture and place his reading of Venezuela and its people on the national stage.

\section{The Politics of Identity}

The socio-political setting of an exhausted political and economic model offered Hugo Chávez a receptive environment in which to develop his political message. While Pérez ostracised the popular classes through his portrayal of the Caracazo uprising, Chávez would place the formerly maligned at the centre of his political narrative. Indeed, Pérez's formerly 'phantasmagorical' subversives would become the authentic Venezuelan 'people' and, in the process, be converted into the subjects of the nation rather than those previously excluded. It is this placement of the popular classes at the heart of political life that underpins the new official 'Bolivarian' identity promoted by Chávez. Central to this process is a historically contingent narrative that placed the Bolivarian leader's own political struggle alongside that of the previously maligned.

Described by Hugo Chávez as a 'massacre' and a 'savage repression' that 'marked my generation', the Caracazo is represented as the foundational myth of the Bolivarian Revolution, as it launched a desire amongst members of Chávez's Movimiento Bolivariano Revolucionario 200 (MBR-200) to join the people in their opposition to the state. ${ }^{37}$ From that point onwards, he argues, MBR-200 could 'no longer be the guardians of a genocidal regime' ${ }^{38}$ Positioning his own political trajectory within the popular discontent generated by the Caracazo, the Bolivarian leader claims that the 1989 uprising acted as a catalyst for a series

35 Ibid., pp. 289-90.

36 Ibid., p. 311.

37 Cited in Harnecker, Hugo Chávez Frías, p. 13.

38 Cited in ibid. 
of discussions within MBR-200 about how to overcome the corrupt Punto Fijo system. The outcome of these discussions was a coup d'état in 1992 launched against the Pérez government. More than a simple coup, however, Chávez claimed that if successful, he would gain popular legitimacy by restoring power to the people via a constituent assembly. ${ }^{39}$ While the coup ended in failure, Chávez has since positioned the events of 1992 within a larger narrative that picks up on the popular resentment of the Caracazo. The actions of 4 February 1992, he claims, are representative of the same revolutionary zeal that the people demonstrated some three years earlier. This shared struggle for change was encapsulated in two words: 'por ahora.' Making a television appearance to call on his co-conspirators to lay down their arms after the failed coup attempt, the then Lieutenant Colonel told viewers that his objectives had not been met 'por ahora' (for now). Stirring popular sentiment that the struggle had only begun, 'por ahora' has since been historicised as a popular rallying cry for the aspirations set loose by the Caracazo. By linking the fortunes of his political trajectory with that of the 'phantasmagorical' subversives, Chávez, in his assent to power, was to represent the arrival of the previously marginalised at the centre of Venezuelan political life.

More than aligning his political history with that of the poorer classes, Chávez specifically traded on popular discontent with the Punto Fijo system. Perceived as responsible for declining living standards, official state institutions could no longer contain popular demands or channel protest through less-disruptive forms of mobilisation, such as marches or legal strikes. ${ }^{40}$ Between 1991 and 1994, the frequency and manner in which Venezuelans took to the streets changed significantly. Protest as a tactic was now used by indigenous communities, street vendors, retired workmen, oil workers, policemen, doctors, nurses and teachers in state schools, in addition to the unemployed, local residents, students and public transport drivers. ${ }^{41}$ Violent protests peaked between 1991 and 1993 during the Pérez government and again between 1995 and 1996 amid a second wave of economic austerity measures referred to as 'la Agenda Venezuela' ${ }^{42}$ Before the Caracazo, confrontational protests accounted for less than onequarter of the total protests. Subsequently, however, this figure rose to average about one-third for the 1990s and reached 43 per cent in the second half of that decade. ${ }^{43}$

\footnotetext{
39 Ibid.

40 For more information on the range of protests, see Lander, E. 2005, 'Venezuelan social conflict in a global context', Latin American Perspectives, vol. 32, p. 29; López-Maya, M. 2002, 'Venezuela after the Caracazo: forms of protest in a deinstitutionalized context', Bulletin of Latin American Research, vol. 21, no. 2, p. 216; Levine, 'Beyond the exhaustion of the model', p. 190; Lupi, J. P. and Vivas, L. 2005, '(Mis)understanding Chávez and Venezuela in times of revolution', The Fletcher Forum of World Affairs, vol. 29, no. 1, p. 91.

41 López-Maya, 'Venezuela after the Caracazo', p. 213.

42 Maya, M. L. and Lander, L. 2005, 'Popular protest in Venezuela: novelties and continuities', Latin American Perspectives, vol. 32, no. 2, p. 97.

43 Ibid., p. 100.
} 
Chávez's language in the lead-up to the 1998 poll spoke directly to these frustrations. Denouncing the old system as 'not defending democracy...[but rather] trying to defend their privileges', Chávez promoted a collective sense of injustice by likening the Punto Fijo system to a 'gangrenous politics', a corrupt system 'encrusted right to the marrow' ${ }^{44}$ Extending the illness metaphor, he claimed that Punto Fijo was 'the most terrible cancer that we have...[in] the body of the Republic'. ${ }^{45}$ This perceived exhaustion of the political system was reflected by an increase in abstention rates for presidential elections from traditional levels of about 10 per cent to 18 and 39.8 per cent in 1988 and 1993 respectively. ${ }^{46}$ Capitalising on such a setting, Chávez maintained that only the return of the 'people' to the heart of Venezuelan politics would arrest this decline: 'we are going to encourage, to push for and to reinforce solidarity in the streets, with the people, through the calling of elections for a national constituent assembly in order to redefine the fundamental base of the republic that came from below. ${ }^{47}$

\section{Which People? Limits to a shift in the politics of identity}

Far from speaking to all Venezuelans, the Bolivarian leader, in calling upon the 'people', does not refer to a civil society of legal equals who share a common national identity. Rather, he depicts el pueblo as the poor majority of Venezuelans who live at the margins of society. ${ }^{48}$ Viewed with this objective in mind, Chávez's references to el pueblo are similar to the 'demos' outlined by Jacques Rancière. In each case, the 'people' are not an ontological whole, but rather are exposed as an outcast group previously excluded in a given order. Chávez affects a constitutive split within the term 'people', differentiating between what Rancière calls a populus and plebs - the whole populace and a maligned part. ${ }^{49}$ Chávez's usage of the 'people' thus seeks to represent all groups that were previously marginalised

\footnotetext{
44 Cited in Molero de Cabeza, L. 2002, ‘El personalismo en el discurso político venezolano: un enfoque semántico y pragmático', Espacio Abierto, vol. 11, no. 2, p. 315.

45 Cited in ibid., p. 319.

46 Almao, V. P. 1998, 'Venezuelan loyalty towards democracy in the critical 1990s', in D. Canache and M. R. Kulisheck (eds), Reinventing Legitimacy: Democracy and political change in Venezuela, Greenwood Press, Westport, Conn., p. 139; Molina, J. E. and Perez, C. 2004, 'Radical change at the ballot box: causes and consequences of electoral behavior in Venezuela's 2000 elections', Latin American Politics and Society, vol. 46, no. 1, p. 116.

47 Cited in Molero de Cabeza, 'El personalismo en el discurso político venezolano', p. 318.

48 Hellinger, D. 2006, 'Tercermundismo and Chavismo', Stockholm Review of Latin American Studies, vol. 1, no. 1, p. 14.

49 Rancière, J. 1998, Disagreement: Politics and philosophy, University of Minnesota Press, Minneapolis, pp. 8-9; Rancière, J. 2001, 'Ten theses on politics', Theory \& Event, vol. 5, no. 3. Giorgio Agamben also refers to this distinction as 'Popolo and popolo' - a classification defined by Agamben as one of the forms of bare life. For more, see Agamben, G. 2000, Means Without End: Notes on politics, University of Minnesota Press, Minneapolis.
} 
by the state. Moreover, by evoking the previously marginalised through his usage of the term 'people', Chávez attempts to appropriate their perspective and expand it to the entire populace. That is, although el pueblo represents the plebs, Chávez makes it reflective of the populus. 'I feel myself President for all', Chávez stated on the third anniversary of his 1998 electoral triumph: 'this revolution is for all, but especially for you the poor, those that were left unprotected during much of the time and were marginalised. ${ }^{50}$ As already noted, however, this reorientation is not a result of the Venezuelan President alone. During the Caracazo uprising, Pérez's 'phantasmagorical subversives' claimed themselves as the legitimate people of the nation. It is this appropriation, and later Chávez's acknowledgment of the 'people' on the national political plain, which demonstrates the shift in the politics of identity.

Although highlighting the placement of the formerly maligned masses at the centre of Chávez's political project, this shift, of itself, is not enough to constitute a new Venezuelan identity. Neither the Caracazo nor Chávez's electoral success acted as a singular foundational moment of rupture whereby a new political subjectivity was created. ${ }^{51}$ The shift in focus was only the first constitutive step in the production of a new identity. As it stands, Chávez's language constitutes a political subjectivity (the 'people'); however, the ideas and demands of the formerly maligned are varied and lack the unity required to produce the new identity. In order for the new 'Bolivarian' identity to have any resonance amongst the polity, references to the 'people' must carry a unifying logic that speaks to, and represents, the diverse ideas and demands of the formerly maligned. It needs to interlock the various ideas and frustrations launched by the Caracazo and the decadence of Punto Fijo, and reorganise them in a harmonious way, so that to refer to one issue comes to evoke another. ${ }^{52}$ To speak of issues relating to housing must also be to evoke concerns over health, education, landownership, social inequalities and so forth. More than material themes, it must also encompass the varied frustrations, ideas, symbols, beliefs and narratives, and re-aggregate them within an official 'Bolivarian' narrative. The resonance of Chávez's language thus becomes temporally contingent on speaking to the (varied) future aspirations of the 'people'.

While acknowledging the production of unity, this is not to suggest that a new official 'Bolivarian' identity is a relatively harmonious set of parts that function smoothly. Rather, its coherence is dependent on blocking and reorganising

50 Cited in Domínguez, M. 2008, 'La pobreza en el discurso del presidente de Venezuela, Hugo Chávez Frías', Discurso \& Sociedad, vol. 2, no. 2, p. 313.

51 Laclau, E. and Mouffe, C. 1985, Hegemony and Socialist Strategy: Towards a radical democratic politics, Translated by W. Moore and P. Cammack, Verso, London, p. 152.

52 Laclau, E. 2006, 'Ideology and post-Marxism', Journal of Political Ideologies, vol. 11, no. 2, p. 109; Laclau, E. 2005, On Populist Reason, Verso, New York, p. 108. Louis Althusser refers to this as a ruptural unity, whereby 'there must be an accumulation of circumstances and currents' in order to construct a unity. For more, see Althusser, L. 1969, For Marx, Translated by B. Brewster, The Penguin Press, London, p. 99. 
certain ideas, symbols, beliefs and narratives. ${ }^{53}$ Moreover, the subjectivity of a given social agent (or more precarious still, of a social collective) can never be finally established as it is provisionally and often precariously constituted of multiple overlapping identities, enabling a plethora of possible constructions, and myriad intertwining subjectivities. ${ }^{54}$ Far from disabling an exploration of identity construction, however, to acknowledge this fragility is to do two things. First, rather than focusing on the contingent nature of identity and its multiple overlapping elements, analysis below centres on one dominant (official Chávez) reading of identity and its attempts to codify what it means to be Bolivarian. In so doing, the point is not to examine the veracity of the official reading, but to explore its specific elements and their attempts to construct a stable identity. ${ }^{55}$ More than just a superficial reading, however, it looks at how specific narratives interact so as to discern both the boundaries they configure and what possibilities they enable. ${ }^{56}$ Second, it is to recognise that the construction of identity is ongoing and can take multiple forms. Be it a reading of the Caracazo that elicits a brave, angry people or commentary on a fraudulent state that stands in relief with a repressed, marginalised populace, the articulation of a Bolivarian identity is ongoing and multidimensional. The 'people', as representatives of a 'Bolivarian identity', become performative subjects that are continuously invoked in Chávez's discourse, be it through a policy position or a particular political narrative. ${ }^{57}$ In this sense, the 'Bolivarian people' are not some pre-existing sociological category but rather come into being through Chávez's discourse as a formerly outcast group now rightfully taking their place at the centre of Venezuelan society. The remainder of this analysis explores this reorientation and the construction of a Bolivarian identity through an analysis of Chávez's political narrative.

\section{The Production of a Bolivarian Identity}

While analysis below centres on Chávez's attempts to speak to and represent the diverse ideas and demands of the formerly maligned, this does not mean that the Venezuelan leader has carte blanche to construct a Bolivarian people. Rather, to be of value, Chávez's statements must not only speak to the experiences of the people, they must also fit within a series of expectations that is temporally

53 Connolly, W. E. 1991, Identity|Difference: Democratic negotiations of political paradox, Cornell University Press, Ithaca, NY, p. 204.

54 Slater, D. 1991, 'New social movements and old political questions: rethinking state-society relations in Latin American development', International Journal of Political Economy, Spring, p. 36.

55 Devetak, R. 2005, 'Postmodernism', in S. Burchill and A. Linklater (eds), Theories of International Relations, Palgrave, London, p. 170.

56 Foucault, The Archaeology of Knowledge and the Discourse on Language, p. 66.

57 Butler, J. 1995, 'For a careful reading', in S. Benhabib, J. Butler, D. Cornell and N. Fraser (eds), Feminist Contentions: A philosophical exchange, Routledge, New York, p. 134. 
contingent on a common understanding of the past and, also, the future. Further to the already mentioned message of an unjust (recent) past associated with the Punto Fijo system, Chávez speaks of a revolutionary (distant) past and a hopeful future. It is through this temporal division that the central themes of past injustice, a return of dignity and ultimate emancipation are elaborated so as to codify a Bolivarian reading of Venezuela and its official identity.

\section{A (Recent) Past of Injustice and the Rise of a Bolivarian People}

Although depictions of an unjust past underpin the shift in the politics of identity by placing the previously maligned at the centre of political life, this message also generates a discourse of blame. Just as the party Acción Democrática was able to claim itself as 'el partido del pueblo' (the party of the people) in opposition to the oppressive regime of General Isaías Medina Angarita, the Bolivarian leader constructs a similar representation of himself and his party today. Be it the oligarchy or the Punto Fijo system itself, this politico-economic elite is placed in opposition to the interests of the 'people' and is blamed for the country's failure to achieve its potential. They were responsible for robbing the nation's wealth and for steering the country away from its glorious destiny. ${ }^{58}$ More than eliciting the two basic identity claims of the present (the 'people' versus the 'oligarchy'), a blame discourse also conveys a sense of righteous indignation that clarifies the meaning associated with each subjectivity. It reinforces a conviction amongst the 'people' of their virtue in contrast with the absolute corruption of those before them. To this extent, the public performance of shaming acts as a mechanism through which to build solidarity around a new Bolivarian identity. ${ }^{59}$ Not only are the 'people' morally superior to the oligarchic elite, the difference between the two is represented as dangerous. The Chávez narrative explicitly feeds into the supposed risk associated with the economic and political elite by emphasising the traumatic history of the Caracazo as a 'massacre' (rather than as '27-F' or 'the events') and by fuelling common perceptions of rampant corruption and the pain caused by widespread and endemic poverty. The blame discourse thus codifies the interpretation of Venezuelan history, whereby any ambiguity in the reading of the Caracazo, for example, is easily clarified as a 'savage repression' by a 'genocidal regime'. ${ }^{60}$ Similarly, Chávez's failed coup attempt is easily portrayed as an attack against a corrupt state in the name of a righteous people.

\footnotetext{
58 This point was initially made in relation to the most recent debt crisis in Argentina, by Armony, A. C. and Armony, V. 2005, 'Indictments, myths, and citizen mobilization in Argentina: a discourse analysis', Latin American Politics and Society, vol. 47, no. 4, p. 44.

59 Locke, J. 2007, 'Shame and the future of feminism', Hypatia, vol. 22, no. 4, p. 148.

60 Brown, W. 1995, States of Injury: Power and freedom in late modernity, Princeton University Press, Princeton, NJ, p. 27.
} 
Although such a setting gave Chávez's claims of a decadent state greater resonance, these sentiments were already common within the South American nation. La paradoja venezolana - the Venezuelan paradox - is a case in point. Unable to explain the contradiction of so much wealth being generated by oil rents amid so much poverty, the indignant citizen reasoned that theft by governing elites was the only explanation for this paradox. ${ }^{61}$ La paradoja not only reinforced the distinction between the people and the elite, it expanded this division to include an ethical struggle whereby the exploitative oligarchic forces needed to be collectively overcome. ${ }^{62}$

While Chávez's narrative of injustice feeds into these concerns, he also offers a hopeful vision of the future. A shameful, corrupt past is recognised so that the dignity of the people can now be restored. Placed against previous injustice, the official narrative of returning dignity to the nation enables Venezuelans to become aware of their inglorious (recent) past, and empowered by its new role in the creation of a just and dignified era: 'Venezuela will be great again, it is on its way towards greatness. Venezuela will be glorious again, it is lifting the flags of glory, the glory of the people, the hope of the people. ${ }^{63}$ The 'people' are at once conscious of how weak they have been and of how strong they could be thanks to the Bolivarian Revolution. Chávez himself gives voice to these expectations: 'the most important thing that Venezuela can have today is not a man, but a conscious people, you conscious of what is happening, awake, conscious, marching. ${ }^{64}$ Moreover, by returning dignity to the 'people', so the argument goes, no longer will they be subservient to the politico-economic elite. 'We the Bolivarians, we the revolutionaries, we are not afraid of any threats by any oligarch no matter how rich or powerful. ${ }^{\prime 5}$ The appeal of the Chávez narrative, beyond mere antagonism directed towards the elite, comes from its ability to both recognise and (re)construct the frustrations and aspirations felt by the formerly maligned. A Bolivarian people are a glorious people who require no external inspiration - nor ought they be subordinate to anyone. ${ }^{66}$ Rather, they will be the inspiration for others. 'Bolivarianism is not only a thesis for Venezuela. We, with much humility, propose it for the world, especially to the

61 Cameron, M. A. and Major, F. 2001, 'Venezuela's Hugo Chavez: saviour or threat to democracy?', Latin American Research Review, vol. 36, no. 3, p. 256; Buxton, J. 1999, 'Venezuela', in J. Buxton and N. Phillips (eds), Case Studies in Latin American Political Economy, Manchester University Press, UK, p. 167.

62 Lupi and Vivas, '(Mis)understanding Chávez and Venezuela in times of revolution', p. 83; De La Torre, C. 2000, Populist Seduction in Latin America: The Ecuadorian experience, Ohio University Center for International Studies, Athens, p. 4.

63 Chávez cited in Moreno, 'Metaphors in Hugo Chavez's political discourse', p. 115.

64 Cited in Zúquete, 'The missionary politics of Hugo Chávez', p. 103.

65 Cited in ibid., p. 100.

66 This point was initially made in relation to the politics of debt in Peru by Weber, C. 1990, 'Representing debt: Peruvian Presidents Belaunde's and Garcia's reading/writing of Peruvian debt', International Studies Quarterly, vol. 34, no. 3, p. 361. 
Latin American and Caribbean world, it is Our America. ${ }^{\prime 67}$ This allusion to 'Our America' and its author, the Cuban revolutionary figure José Martí, points to the second temporal dimension in Chávez's narrative: a distant, revolutionary past.

\section{A (Distant) Revolutionary Past and the People's Emancipation}

More than any of his predecessors, Chávez often invokes historical figures and events when surveying the contemporary political landscape. The ideals of the War of Independence that liberated Venezuela from Spain, for example, are replayed today for new emancipatory purposes. ${ }^{68}$ Evoking the Federal Wars (1859-63) in the lead-up to the 2004 elections to recall his presidency, Chávez equated the 'No' campaign with the Battle of Santa Inés of 1859. In this battle, General Ezequiel Zamora used tactical retreats (just as Chávez utilised the recall elections) to draw his conservative enemies into a strategic trap. ${ }^{69}$ Similarly, present-day policies are named after historical figures with the effect of reinforcing a connection with the revolutionary past. Social-welfare and education programs are named after figures such as Ezequiel Zamora (for land reform), Simón Robinson (a pseudonym for Simón Rodríguez; for literacy), José Félix Ribas (another figure in the fight for Venezuelan independence; for education) and Guaicaipuro (an indigenous anti-colonial resistance leader; for indigenous rights). ${ }^{70}$

The synthesis between the past and present is more than a static invention of tradition. By isolating and reifying particular elements of Venezuelan history, Chávez is also able to naturalise both the subjectivities ('people' versus the elite) and the narratives (returning dignity) within his political discourse. Evoking a sense of continuity among the subject positions of the two epochs, Chávez noted that ' $[\mathrm{t}]$ he oligarchy of today are the same as yesterday [only] with different faces and names and the Bolivarians of today are the same as yesterday with different faces and names'. ${ }^{71}$ Placing the antagonistic positions of the 'people' and the 'elite' in a historical context, Chávez is able to naturalise this classification of Venezuelan society by acknowledging its existence in the past. 'You know that Bolívar was betrayed by the predatory oligarchy, this same oligarchy that now...

67 Chávez, H. 2006, 'Discurso con motivo del inicio de la Cátedra "Simón Bolívar" en la Universidad Nacional de Brazilia, "O nos unimos o nos hundimos", Brazil, May 6 1999', in S. Rinaldi (ed.), La Unidad Latinoamericana, Ocean Sur, Bogota, p. 4.

68 Sanoja, P. 2009, 'Ideology, institutions and ideas: explaining political change in Venezuela', Bulletin of Latin American Research, vol. 28, no. 3, p. 399.

69 Hellinger, D. 2005, 'When "no" means "yes to revolution": electoral politics in Bolivarian Venezuela', Latin American Perspectives, vol. 32, no. 3, p. 13.

70 Zúquete, 'The missionary politics of Hugo Chávez', p. 109.

71 Cited in Arreaza, I. C. 2003, 'El discurso de Hugo Chávez: Bolívar como estrategia para dividir a los venezolanos', Boletín de Lingüística, vol. 20, p. 32. 
threatens in a ridiculous manner this revolutionary government. ${ }^{\prime 72}$ Not only was the nation constructed in a struggle against an oligarchy, Chávez argues, these elites have always acted at the expense of the people. Accordingly, the hardships and the challenges faced today by the 'people' are, in essence, the same as those that the people of Venezuela suffered in the past. ${ }^{73}$ The appeal to lost traditions, the recovery of histories and the construction of an alternative historical narrative all serve to exclude the oligarchy, painting them as impediments to the Bolivarian Revolution, while also reinforcing the primacy of the 'people'.

Moreover, the narrative of historical continuity also promotes a sense of a common emancipatory outcome: 'we are the same fighters for independence, for dignity, for liberty and for equality for our people. ${ }^{74}$ By configuring this historical link, Chávez is able to reinforce the central themes of the Bolivarian narrative with the quest for 'dignity and equality as prescient today as it was 200 years ago'.$^{75}$ To this extent, the synthesis of the past with the present (re) introduces the theme of emancipation as the historical struggle of the 'people'. '[W]e are this year precisely, commemorating 180 years since the heroics of Ayacucho, where the united peoples converted into liberation armies...[and] overthrew imperial Spain... Today before the evident failure of neoliberalism... our peoples are retaking that spirit. ${ }^{.76}$

The mythical weight of Simón Bolívar-who liberated present-day Bolivia, Colombia, Ecuador, Panama, Peru and Venezuela during his own lifetime (1783-1830) - is central to an emancipatory struggle. The historical importance of Bolívar within Venezuela provides Chávez with a broad framework within which to situate his own emancipatory 'Bolivarian' representation. Dating from 1842, Venezuelan presidents of different ideological persuasions have invoked the image of Bolívar. Whether it was President José Antonio Páez (1830-35), who ordered the repatriation of Bolívar's remains in order to arrest a slide

\footnotetext{
72 Cited in ibid., p. 34.

73 Zúquete, 'The missionary politics of Hugo Chávez', p. 102.

74 Cited in Arreaza, 'El discurso de Hugo Chávez', p. 32.

75 Persaud, 'Situating race in international relations', p. 67.

76 Chávez, H. 2006, ‘Discourso en la Instalación de la XII Cumbre de Jefes de Estado y de Gobiernos del G15, Teatro Teresa Carreño, Caracas 27 February 2004, “El Sur También Existe"”, in S. Rinaldi (ed.), La Unidad Latinoamericana, Ocean Sur, Bogota, pp. 29-30. Beyond Bolívar himself, the Venezuelan President uses a combination of historical sources, known collectively as 'el árbol de las tres raices' (the tree with three roots) to underpin the Bolivarian narrative. Recycling existing ideas and fitting forgotten actors and events into new situations, the historicising of Bolivarianism is based on a nationalist trinity of figures: Simón Bolívar, Ezequiel Zamora and Simón Rodríguez. Zamora, the federalist martyr from the same llanos region of Barinas as Chávez, is exalted for his anti-oligarchic rhetoric and has come to symbolise the unity between the peasantry and the army. Simón Rodríguez is portrayed in a similar light. As Bolívar's tutor and mentor, Rodríguez comes into the trinity by virtue of his educational qualities and the redeeming value of educating the masses. Additionally, Rodríguez is represented as a force for independence, with his famous comments 'we innovate or we will disappear' recontextualised to appeal to a nationalist doctrine of self-determination and emancipation. For more, see, Sanoja, 'Ideology, institutions and ideas', pp. 401, 406; and Hellinger, 'Tercermundismo and Chavismo', p. 11.
} 
in his popularity, or Hugo Chávez today, Bolívar has served as a nationalist veneer within which policy decisions are legitimated and political careers are energised..$^{77}$ Outlining the mythology surrounding the Liberator's life, German Carrera Damas describes the cult of Bolívar as a complex historical-ideological formation that permits the projection of Bolívar's values (however defined) over all aspects of political life. ${ }^{78}$ As a result, Bolívar has become a divine-like figure - 'the Son of Venezuela, its immortal Creator' — who represents the highest values of the people. ${ }^{79}$ The cult of Bolívar enables President Chávez to activate a particular reading of the Liberator and reinscribe a more radical, emancipatory interpretation of an already established nationalist ideology.

The task below is to locate the particularities (focal points and silences) in the Chávez usage of the Liberator. Indeed, amid the multiple representations of Bolívar, the question of interest becomes how Chávez is able to turn a member of one of the largest landowning families of the Creole oligarchy, a provincial leader and a liberal ideologue into a figure who speaks to the 'people'.$^{80} \mathrm{In}$ part, he is able to do so by simplifying the complex story of Bolívar, and by reassembling the already existing myths regarding Bolívar's life and times. While not discarding the traditional, liberal readings of Bolívar-readings that pose the Liberator as Venezuela's greatest exponent of the concepts of liberty and equality - the Chávez interpretation radicalises these concepts. ${ }^{81}$ Bolívar's concern for freedom and the national transcendence of exploitation (both foreign and domestic) is emphasised over themes of political equality. Similarly, on this issue of political equality, a more radical notion of natural equality is extrapolated.$^{82}$ While ideas associated with the European Enlightenment and the French Revolution served as a template for Bolívar's feelings on republicanism and the centralised role of government, Chávez localises these themes and, in the process, affects a more radical reading:

[W]e were born for liberty, they ['imperialist infiltrators'] were born for world domination; we were born Bolivarian, we were born together with el pueblo... and we are here to carry out the mandate of Simón Bolívar, in order to...defend the guarantees of the people, the happiness of the people, the freedom of the people, not to dominate them or to insult, nor violate them. ${ }^{83}$

\footnotetext{
77 Lupi and Vivas, '(Mis)understanding Chávez and Venezuela in times of revolution', p. 94; Capriles, C. 2008, ‘The politics of identity: Bolívar and beyond', ReVista Harvard Review of Latin America, vol. VII, no. 1, p. 9.

78 Carrera Damas, G. 1973, El Culto de Bolivar: Esbozo para un estudio de la historia de las ideas en Venezuela, Ediciones de la Biblioteca Caracas, Caracas, p. 21.

79 Ibid., p. 61

80 Coronil and Skurski, 'Dismembering and remembering the nation', p. 296; Cannon, 'Venezuela, April 2002', p. 287.

81 Cannon, 'Venezuela, April 2002', p. 287.

82 Sanoja, 'Ideology, institutions and ideas', p. 402.

83 Chávez, H. 2006, ‘Celebración del VII Aniversario del Gobierno Revolucionario Bolivariano, Sala Ríos Reina, Teresa Carreño Theatre, Venezuela, 2 February 2006, “Hemos echado las bases de lo que estamos
} 
The qualities of liberty, equality and fraternity are elevated to an emancipatory struggle against the despotism and inequality of political and economic power demonstrated in Chávez's readings of the recent past. ${ }^{84}$

In emphasising the social-justice dimension of the Liberator, Chávez aligns Bolívar with steps to return dignity to the people. The Liberator gave 'land to the peasants in order to liberate them from slavery, from hunger and from misery, for this reason the revolution of independence was consolidated with the support of the Venezuelan people' ${ }^{85}$ Moreover, in affecting this radical reading, Chávez both emphasises and confines the Liberator's emancipatory value to the 'people'. While other readings of liberation call attention to the equality given Creoles in respect to their local colonial equivalents, the Chávez narrative emphasises the freedom of slaves from their owners, and the indigenous struggle for equality in front of the strong landed and commercial aristocracy. ${ }^{86}$ 'The liberation of slaves, the liberation of Indians, the dividing of land for the Indians, for the poor, that all should be equal, that freedom without equality has no meaning, it was for this that the oligarchy of the Americas overthrew him [Bolívar].' ${ }^{87}$ This emancipatory reading is forwarded despite the abolition of slavery occurring as a result of political expediency on the part of Bolívar so as to obtain military support from Haiti. Neither Bolívar's political calculations nor the equality given to Creole elites is, however, put forward by a Venezuelan President intent on fashioning a more radical Liberator so as to legitimate his own Bolivarian project.

Having made an investment in certain emancipatory accounts of who Bolívar was, Chávez is able to draw dividends on these representations. ${ }^{88}$ As a defender of social justice and equality, Bolívar's struggle can be repositioned and applied to the enduring social and political asymmetries of today. ${ }^{89}$ Referring to the Battle of Carabobo that sealed the country's independence, Chávez said 'that battle is the same struggle as today. This is the continuation of that revolution, the Bolivarian Revolution. ${ }^{\prime 90}$ The present-day Bolivarian project embodies the same emancipatory quest for dignity and justice as did the actions of Bolívar.

\footnotetext{
comenzando a construir"', in S. Rinaldi (ed.), La Unidad Latinoamericana, Ocean Sur, Bogota, p. 324.

84 Carrera Damas, El Culto de Bolivar, p. 42.

85 Domínguez, 'La pobreza en el discurso del presidente de Venezuela, Hugo Chávez Frías', pp. 308-9.

86 Carrera Damas, El Culto de Bolivar, p. 44.

87 Chávez, H. 2006, 'La Revolución Bolivariana y la Construcción del Socialismo en el Siglo XXI, XVI Festival Mundial de la Juventud y los Estudiantes, Teatro Teresa Carreño, Caracas, 13 August 2005, “Que Podamos Decir dentro de 10 Años, dentro de 20 Años: la Historia nos Absolvió"”, in S. Rinaldi (ed.), La Unidad Latinoamericana, Ocean Sur, Bogota, p. 197.

88 Beier, J. M. 2005, International Relations in Uncommon Places: Indigeneity, cosmology, and the limits of international theory, Palgrave, New York, p. 17.

89 Sanoja, 'Ideology, institutions and ideas', p. 404.

90 Cited in Moreno, 'Metaphors in Hugo Chavez's political discourse', p. 206.
} 
These representations enable Chávez to absorb the spirit of emancipation and place himself and his Bolivarian project as the natural heirs to the life and work of Bolívar.

Deceived during his time, already dying, almost solitary, betrayed, expelled from here, he [Bolívar] said 'the great day of South America is yet to arrive'. Two hundred years later we believe that now the day of the Americas has arrived, and more than just America, the great day of the people. The great day of freedom, of equality and of justice is arriving. ${ }^{91}$

Carrying the Bolivarian sword into the future, Chávez now makes possible the emancipation previously unachieved by Bolívar. Indeed, far from a failure, Bolívar comes to represent all that was not obtained during the independence struggle in the first half of the nineteenth century. ${ }^{92}$ 'Simón Bolívar, father of our patria [homeland] and guide of our revolution, swore not to give rest to his arm, nor respite to his soul, until America was free. We will not give rest to our arms, nor respite to our souls until we save humanity. ${ }^{93}$ Speaking to this emancipation, on the seventh anniversary of his coming to power, Chávez told the assembled that today, thanks to the Bolivarian Revolution, Venezuela is a 'society totally different to that of exclusion and privilege'. As a result, ' $[w]$ hat is happening now is a truly second independence' ${ }^{94}$ Failures of the eighteenth and nineteenth centuries become the possibilities of what Chávez has termed 'twenty-first-century socialism'.

\section{Conclusions}

A new 'Bolivarian' identity was predicated on a shift in the politics of identity that placed the previously maligned masses at the centre of political life. With the former 'phantasmagorical subversives' and impediments to national progress located at the forefront of Venezuelan politics, Chávez elicited and expanded upon the experiences of the 'people' so as to make their history congruent with that of the nation. Examining the social interface between the Chávez narrative and its resonance amongst the polity, it was found that the shift in identity was enabled by a common belief in the exhaustion of the previous politico-economic structures associated with the Punto Fijo system. The rise in popular protests against official austerity measures, in addition to the increase in abstention

\footnotetext{
91 Chávez, 'La Revolución Bolivariana y la Construcción del Socialismo en el Siglo XXI', p. 198.

92 Carrera Damas, El Culto de Bolivar, p. 55.

93 Chávez, H. 2006, ‘LX Asamblea General de la Organización de Naciones Unidas, New York 15 September 2005, "El sueño de la paz mundial necesita alas para volar"”, in S. Rinaldi (ed.), La Unidad Latinoamericana, Ocean Sur, Bogota, p. 212.

94 Chávez, 'Celebración del VII Aniversario del Gobierno Revolucionario Bolivariano', p. 314.
} 
rates for presidential elections, reflected popular perceptions of a corrupt state. Picking up on these perceptions, Chávez's descriptions of the Caracazo as a 'massacre' and of the Punto Fijo system as a 'gangrenous politics' not only reinforced the need for change, they also placed his Bolivarian Revolution as best equipped to dramatically reorientate Venezuelan society.

Having demonstrated the shift in identity, attention then turned to the construction of a new 'Bolivarian' identity. Rather than being authored by a simple pueblo/oligarquia binary, however, the new identity was dependent on a matrix of history and narrative. Within this matrix, Chávez sought to bring together the various aspirations of the 'people' by constructing a recent past of injustice and a distant, revolutionary past. Chávez spoke to the disenchantment with the Punto Fijo system, but did so as a means of consigning such hardship to the past. Buttressing this argument were allusions to a more distant revolutionary past, which, in turn, served at least two rhetorical purposes. First, the links forged between the Chávez administration and the revolutionary past enabled the Venezuelan President to present the recent Punto Fijo past as an anomaly in Venezuelan history. Indeed, more than making static allusions to events 200 years ago, Chávez, by evoking the dignity of the Liberator, claimed to be returning the nation to a more just normality. Second, the supposed revolutionary links were also based on the promise of emancipation to come. The present-day Bolivarian Revolution would fulfil the emancipatory potential unattained by Bolívar himself. This Bolivarian world view - encompassing both a revolutionary past and the promise of emancipation - thus sought to codify the multiplicity of frustrations, ideas, symbols, beliefs and demands into a shared view. Significantly, however, it was the investment in an emancipated future that acted as the cornerstone of Bolivarian politics. Indeed, in the lead-up to the 1998 poll, an improvement in the socio-political setting and the disavowal of the Punto Fijo system were the principal factors that determined Chávez's political legitimacy. Moreover, the subsequent investment made in a new Bolivarian identity was predicated on the betterment of the lives of Venezuelans. To refer to a Bolivarian 'people', therefore, was to refer to an emancipated people.

The link between the promise of emancipation to come and the Bolivarian identity exhibited a symbiotic relationship between the 'people' and Chávez. On the one hand, by reifying the maligned masses and their interests, the Venezuelan President was able to justify his policy initiatives as furthering the people's emancipation. Be it the successful 'no' vote in the 2004 recall election or the exclusion of the oligarchic elite from political life, both were framed as consistent with the people's emancipation. On the other hand, by claiming that it acted in the historical interests of the formerly marginalised, the Bolivarian Revolution came to speak for the 'people'. Indeed, the 'people' became increasingly dependent on the Chávez presidency, not only for their 
recognition on the national political stage, but also because their interests were interpreted for them by the Chávez administration. Looking forward, there is a potential danger in this scenario should there develop a meaningful distinction between the leader and the led. That is, if the interests of the formerly maligned come to differ significantly from those constructed by Chávez for the 'people' then the resonance of the Bolivarian narrative and the political longevity of Chávez himself are likely to be limited. The question becomes for how long can the promise of emancipation resonate if an actual betterment in the lives of the 'people' fails to materialise? While Chávez was able to affect a shift in the politics of identity - an accomplishment for which he deserves credit - the permanence of this movement remains contingent on a receptive audience mindful of their past exclusion, but also weary of previous disappointment. 